\title{
Corrections for Flora Neotropica Monograph 114: Celastraceae (Hippocrateoideae e Salacioideae)
}

\author{
JULIO A. LOMBARDI
}

Departamento de Botânica, Universidade Estadual Paulista, Av. 24-A 1515, Bela Vista, Caixa Postal 199, 13506-900, Rio Claro, São Paulo, Brazil; e-mail: cissus@rc.unesp.br

The recently published monograph (Lombardi, 2014) on the Celastraceae (Hippocrateoideae and Salacioideae) contained two items that need correction, neither of which affects the validity of the published names of the species under the International Code of Nomenclature for algae, fungi, and plants (Melbourne Code) (McNeill et al., 2012).

First, Prionostemma aspera (pages 4, 5, 8, 36, $38,39,184$ and 224) should be correctly spelled throughout as Prionostemma asperum.

Second, on page 154, the type citation (locality and collection date) for Salacia viridiramis Lombardi, sp. nov. was incorrectly stated. It was stated as "Peru. Madre de Díos: Manu Prov. Puerto Maldonado, Los Amigos Biological Station, Madre de Díos River, ca $7 \mathrm{~km}$ upriver from mouth of Río Los Amigos, 22 set 2002 (fl, fr im), M. Aulestia 3366 (holótipo, MO; isótipo, BHCB)." The correct citation is as follows: "11-32. Salacia viridiramis
Lombardi, sp.nov. Tipo: Equador. Francisco de Orellana: Aguarico, Reserva Etnica Huaorani, carretera y oleoducto de Maxus, km 1116, ramal de carretera al pozo Iro, $\mathrm{km} \mathrm{4,} 9$ fev 1995 (fl), M. Aulestia 3366 (holótipo, MO 5808563; isótipo, BHCB)." The collector, collection number, and herbarium acronyms of the holotype and isotype remain the same. This correction does not affect the validity of publication of the name Salacia viridiramis Lombardi (Fl. Neotropica Monogr. 114: 154, 2014).

\section{Literature cited}

Lombardi, J. A. 2014. Celastraceae (Hippocrateoideae e Salacioideae). Flora Neotropica Monograph 114: 1-240.

McNeill, J. et al. (eds.). 2012. International Code of Nomenclature for algae, fungi, and plants (Melbourne Code). Regnum Vegetabile 154: 1-208. 